\title{
Perioperative considerations in a girl with Clanzmann thrombasthenia. Case report
}

\section{Consideraciones perioperatorias en niña con trombastenia de Glanzmann. Reporte de caso}

\author{
Alexander Trujillo Mejía ${ }^{\text {a-c }}$ (D), Carolina López Pérez ${ }^{d}$ (D) \\ ${ }^{a}$ Graduate Anesthesia Program, Universidad de Caldas. Manizales, Colombia. \\ ${ }^{\mathrm{b}}$ Medicine Program, Universidad de Manizales. Manizales, Colombia. \\ ' Rafael Henao Toro Children's Hospital. Manizales, Colombia. \\ d Epidemiology Specialist, Universidad Autónoma de Bucaramanga. Bucaramanga, Colombia.
}

Correspondence: Universidad de Caldas, calle 65\# 26-10, Manizales, Colombia. E-mail: alexander.trujillo@ucaldas.edu.co

\section{What do we know about this problem?}

Conventional coagulation tests are not very useful in patients with Glanzmann thromboasthenia.

What is the contribution of this study?

Thromboelastic testing may be used to guide perioperative hemostatic management in these patients.

How to cite this article:

Trujillo Mejía A, López Pérez C. Perioperative considerations in a girl with Glanzmann thrombasthenia. Case report. Colombian Journal of Anesthesiology. 2021;49(1):e916.

\section{Abstract}

\section{Introduction}

Glanzmann thromboasthenia is a rare congenital bleeding disorder caused by a mutation in platelet glycoprotein $\mathrm{a}-\mathrm{II} b$ and $\beta_{3}$ encoding genes (ITCA2B; 607759 and ITCB3; 173470) in chromosomes $17 q 21.31$ and 17q21.32, respectively, which results in a qualitative or quantitative alteration of the platelet integrin allb $\beta_{3}$ (glycoprotein IIb/IIla) receptor. Glanzmann thromboasthenia is classified as type I when less than $5 \%$ of glycoprotein allb $\beta 3$ is expressed, and as type II when more than $5 \%$ is expressed.

\section{Case presentation}

Description of the perioperative management of a 13-year-old female patient with Glanzmann thromboasthenia who underwent endoscopic anterior bilateral ethmoidectomy. Management was centered on prophylactic platelet transfusion plus the use of tranexamic acid, as well as thromboelastographic determination of hemostasis. There were no bleeding complications during or after the procedure.

\section{Conclusiones}

Pediatric patients with Glanzmann thromboasthenia are at a high risk of perioperastive bleeding. Platelet transfusion is the best prophylactic and therapeutic alternative; however, even in the absence of anti-platelet antibodies, it may not be effective, and viscoelastic testing must be used for assessment during the surgical procedure in order to improve patient safety.

\section{Keywords}

Glanzmann thrombasthenia; recombinant FVIla; platelet transfusions; thrombelastography; case report. 


\section{Resumen}

\section{Introducción}

La trombastenia de Glanzmann es un trastorno hemorrágico congénito infrecuente, causado por mutación en los genes que codifican las glucoproteínas plaquetarias a-IIb (ITCA2B; 607759) y $\beta 3$ (ITCB3; 173470) en los cromosomas 17q21.31 y 17q21.32, respectivamente, alterando cualitativa o cuantitativamente al receptor plaquetario de integrina allbß3 (glucoproteína IIb/IIla). La trombastenia de Glanzmann se clasifica como tipo I cuando se expresa menos del $5 \%$ de la glucoproteína allbß3 y como tipo II, cuando es mayor al $5 \%$.

\section{Presentación del caso}

Se describe el manejo perioperatorio de una paciente de 13 años de edad con trombastenia de Glanzmann, sometida a etmoidectomía anterior bilateral endoscópica. El manejo se centró en la transfusión profiláctica de plaquetas y ácido tranexámico, así como en la evaluación de la hemostasia con tromboelastografía. No hubo complicaciones hemorrágicas durante y después del procedimiento.

\section{Conclusiones}

Los pacientes pediátricos con trombastenia de Glanzmann tienen alto riesgo de hemorragia perioperatoria. La transfusión de plaquetas es la mejor alternativa profiláctica y terapéutica; sin embargo, incluso en ausencia de anticuerpos antiplaquetarios, puede no ser efectiva y debe evaluarse mediante pruebas viscoelásticas durante los procedimientos quirúrgicos para mejorar la seguridad del paciente.

\section{Palabras clave}

Trombastenia de Glanzmann; factor VIla recombinante; transfusión de plaquetas; tromboelastografía; reporte de caso.

\section{INTRODUCTION}

Glanzmann thromboasthenia (CT) is a rare $(1 / 1,000,000)$ autosomal recessive disorder (1) caused by a mutation in platelet glycoproteins allb encoding genes (ITCA2B; 607759 and ITCB3; 173470) in chromosomes $17 q 21.31$ and 17q21.32, respectively. This gives rise to a qualitative or quantitative alteration of the platelet integrin allb $\beta_{3}$ (glycoprotein Ilb/IIla) receptor that acts as fibrinogen receptor on the platelet surface (2). GT is classified as type I when $<5 \%$ of glycoprotein allb $\beta_{3}$ is expressed, or as type II when $>5 \%$ is expressed. Bleeding manifestations appear in early childhood, and more than $75 \%$ of the patients require blood product transfusions for the rest of their lives. Prothrombin time (PT), partial thromboplastin time (PTT) and platelet count (PC) are generally normal and cannot be used to assess hemostasis or the effectiveness of the treatments administered to these patients.

The following is a description of a case managed successfully with thromboelastography-guided prophylactic use of tranexamic acid (TA) and platelet transfusion (PTr) in a pediatric patient taken to a surgical procedure associated with a high risk of bleeding.

\section{CASE DESCRIPTION}

A 13-year-old caucasian female patient, attending secondary school and coming from the urban area of Manizales, Colombia, with a diagnosis of GT, assessed in the pre-anesthesia consult before undergoing endoscopic anterior bilateral ethmoidectomy plus turbinoplasty due to chronic pansinusitis and turbinate hypertrophy. The patient was diagnosed at 11 years of age by the hematologist due to episodes of epistaxis, spontaneous bruising, dental exfoliation with bleeding and hemorrhage following cauterization of septal varices. No genetic variant was found on clinical exome sequencing. She had no history of menarche, allergies, toxic substances, drugs or prior transfusions. Findings on clinical examination were normal, with no difficult airway predictors. Weight $41.7 \mathrm{~kg}$, height $150 \mathrm{~cm}$. Results of preoperative testing: hemoglobin $13.5 \mathrm{~g} /$ $\mathrm{dL}-1$, hematocrit $41.6 \%$, leukocytes 6,190 $\mu L-1, \quad$ PC $335.000 \mu L-1$, PT 13.2 seconds, PTT 30 seconds, INR 0.97; blood group O-positive. Permissible blood loss of 1,556 $\mathrm{mL}$. Red blood cells, fresh frozen plasma and platelet apheresis.

The hematologist prescribed transfusion of one unit of leukocyte-reduced apheresisderived platelets before the surgery, and hemostasis was assessed two hours later using tromboelastography (TEG), with the following results: response time ${ }^{\circledR}, 5.1$ min; coagulation time $(K), 3.5 \mathrm{~min}$; a angle, $50.6^{\circ}$; maximum amplitude (MA), $56.8 \mathrm{~mm}$ (reference values: 5-10 minutes, 1-3 minutes, 53-72 and 50-70 $\mathrm{mm}$, respectively) (Figure 1 ). The decision was to take the patient to surgery.

TA was used as an initial bolus of $10 \mathrm{mg} /$ $\mathrm{kg}$ followed by an infusion of $2 \mathrm{mg} / \mathrm{kg} /$ hour during the surgery. Thermal protection and standard monitoring were used. Remifentanil, propofol and rocuronium were used for general anesthesia induction, and sevoflurane and remifentanil were used for maintenance. An Oral RAE No. 6.5 tube was used for tracheal intubation. Dexamethasone and ondansetron were administered for antiemetic prophylaxis. Analgesic management consisted of paracetamol and hydromorphone. The 
FICURE 1. Thromboelastography performed 2 hours after platelet transfusion.

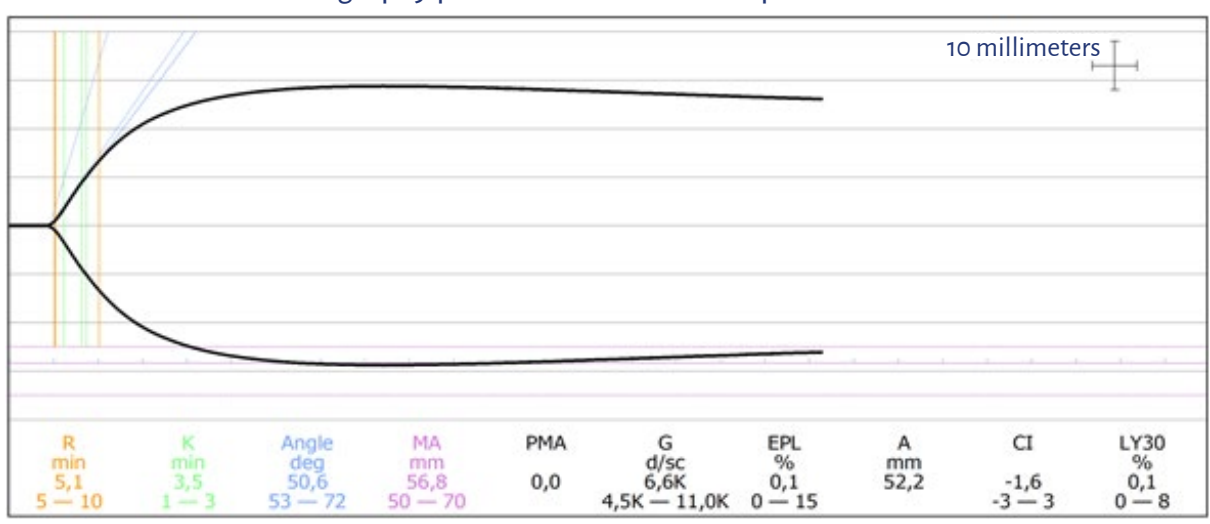

SOURCE: Authors.

surgical procedure lasted 60 minutes and blood loss was minimum. TA was continued during the next two hours after surgery, followed by oral administration of $500 \mathrm{mg}$ every eight hours until three doses were completed. The results of the postoperative complete blood count were hemoglobin $13.1 \mathrm{~g} / \mathrm{dL}-1$, hematocrit $39.1 \%$ and PC $360,000 \mathrm{~g} / \mathrm{dL}-1$. There were no postoperative complications or evidence of bleeding, and the patient was discharged the following day. There were no bleeding episodes during the first 30-day follow-up period (Figure 2).

\section{DISCUSSION}

Perioperative management of pediatric patients with CT poses several challenges: high risk of bleeding, low permissible blood losses, use of hemostatic agents that entail the risk of complications, and little use for conventional coagulation tests. Therapeutic options include TA, PTr and recombinant factor VIla (rFVIla). TA has been shown to be useful in association with other therapies in patients with CT (1). It is an anti-fibrinolytic agent that inhibits plasminogen and reduces plasmin production, preventing clot lysis. Recombinant factor VIla is an option in patients with anti-integrin allb $\beta_{3}$ and/or HLA antibodies, and refractory to $\mathrm{P} \operatorname{Tr}(3-5)$. It is a preferred option in women in childbearing age in order to avoid PTr-related antibodies which may cross the placenta and produce fetal thrombocytopenia (associated with intrauterine demise and intracranial bleeding)(1). PTr is the best option for bleeding prevention or treatment in patients with $\mathrm{CT}(6)$; however, its effectiveness may be impaired by several factors. Al-Battat et al. (7) found that conventional platelet doses may not be sufficient for adequate hemostasis given that endogenous platelets are bigger in number than transfused platelets and adhere in a higher proportion at the site of injury. Moreover, reactive isoantibodies against integrin allb $\beta_{3}$ and/or major histocompatibility complex class I molecules in patients with prior transfusions may block platelet aggregation and lead to a rapid clearance of transfused platelets (8). This situation is difficult to ascertain in the surgical setting because it requires antibody measurements which take time and are not always available.

The patient had bleeding complications during a previous surgery before she was diagnosed. For this reason, the hematologist ordered prophylactic use of leuko-reduced PTr before the surgery. PTr prophylaxis is effective for the prevention of perioperative bleeding in patients with $\mathrm{CT}$, preferably with HLA-compatible platelets or, if not, leuko-reduced platelets to avoid alloimmunization (1). Although the patient had not received prior transfusions that could put her at risk of having antithrombocyte or anti-platelet antibodies, it is reasonable to use more objective measurements of the quality of hemostasis before surgery, according to the findings by Al-Battat et al. (7). For this reason, the surgical team decided to use TEC before the

FIGURE 2. Timeline of clinical events.

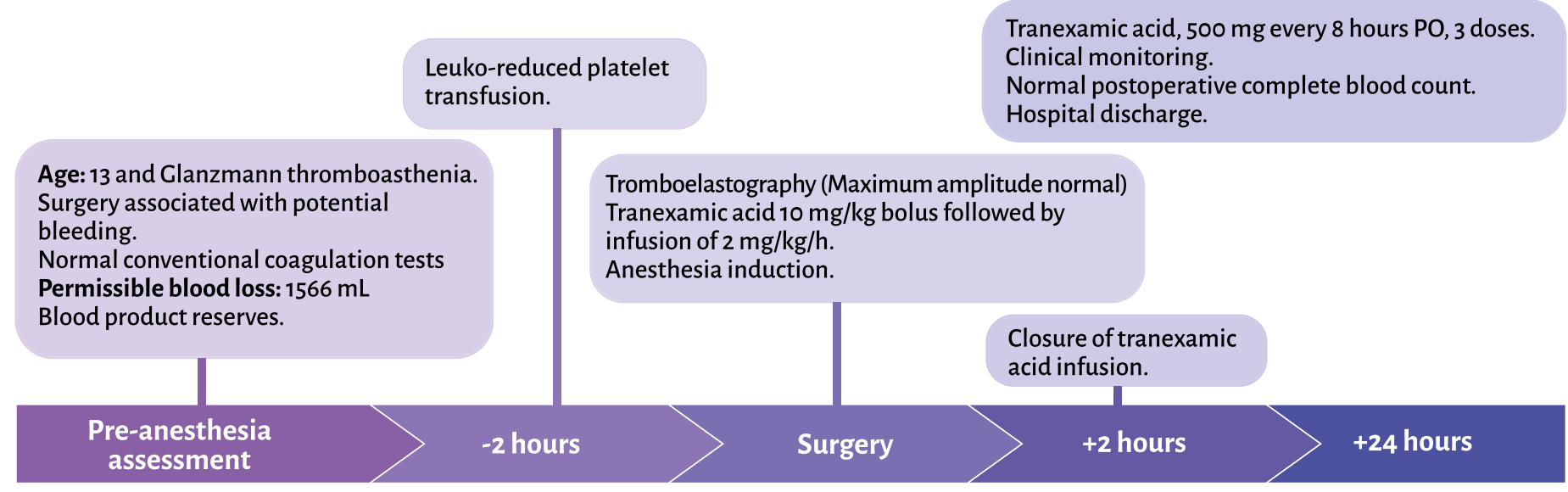

SOURCE: Authors. 
procedure in order to assess the effect of the treatment. Some authors have described the usefulness of viscoelastic tests for the determination of hemostatic status during the surgical procedure and as guidance for therapeutic measures in patients with GT $(9,10)$. MA, which assesses maximum clot stiffness (depending on platelet function and number and, to a lesser degree, fibrin formation) was normal, as were all the other measured parameters. Consequently, it was considered safe to perform the procedure. In this context, TEC vas a valuable tool for making a quick determination of hemostatic status, favoring more objective decisions, and improving patient safety.

Finally, surgical planning and teamwork were crucial for the success of the procedure.

\section{CONCLUSIONS}

Pediatric patients with GT are at a high risk of bleeding during and after surgery. PTr is the best prophylactic and therapeutic option; however, even in the absence of anti-platelet antibodies, its effectiveness may be compromised. Therefore, viscoelastic tests are useful for determining treatment efficacy and enhancing patient safety during the surgical procedure.

\section{Authors' contributions}

ATM: Study planning, data collection, data analysis and final drafting of the manuscript. CLP: Study planning, data collection, data analysis and final drafting of the manuscript.

\section{ETHICAL CONSIDERATIONS}

\section{Human and animal protection}

The authors declare that no experiments in humans or animals were carried out for this research.

\section{Data confidentiality}

The authors declare that they have followed the protocols on patient information disclosure implemented by their institution.

\section{Right to privacy and informed consent}

The authors declare that no patient data appear in this paper. Informed consent in writing was obtained for publishing the case, ensuring protection of patient anonymity. The informed consent document is kept by the corresponding author.

\section{Funding}

The authors declare that they did not receive any form of financial support.

\section{Conflict of interests}

The authors declare having no conflict of interest.

\section{REFERENCES}

1. Solh T, Botsford A, Solh M. Glanzmann's thrombasthenia: pathogenesis, diagnosis, and current and emerging treatment options. ] Blood Med. 2015;6:219-27.

2. Barg AA, Hauschner $H$, Misgav M, Lubetsky A, Levy-mendelowitz S, Livnat $T$, et al. A novel approach using ancillary tests to guide treatment of Clanzmann thrombasthenia patients undergoing surgical procedures. Blood Cells, Mol Dis. 2018;72:44-8. https://doi. org/10.1016/j.bcmd.2018.07.003

3. Franchini M, Lippi G. NovoSeven (recombinant factor VIla ) for the treatment of bleeding episodes and perioperative management in patients with Glanzmann 's thrombasthenia. Expert Rev Hematol. 2014;733-40.

4. Poon M, Oiron R, Zotz RB, Bindslev N, Nicola $M$, Di $D$, et al. The international, prospective Glanzmann Thrombasthenia registry: treatment and outcomes in surgical intervention.Coagulation \& Its Disorders. 2015(100):1038-44.

5. Rajpurkar M, Chitlur M, Recht M, Cooper DL. Use of recombinant activated factor VII in patients with Glanzmann's thrombasthenia: a review of the literature. Hemophilia. 2014;464-71.

6. Poon M, Di G, Zotz R. New Insights into the treatment of Glanzmann thrombasthenia. Transfus Med Rev. 2016;30(2):92-9. http:// dx.doi.org/10.1016/j.tmrv.2016.01.001

7. Al-Battat S, Rand ML, Bouskill V, et al. Glanzmann thrombasthenia platelets compete with transfused platelets, reducing the haemostatic impact of platelet transfusions. Br] Haematol. 2018;181(3):410-3. doi:10.1111/bjh.14623

8. Fiore $M, D^{\prime}$ Oiron $R$, Pillois $X$. Antiallb $\beta_{3}$ immunization in Glanzmann thrombasthenia: review of literature and treatment recommendations. $\mathrm{Br}]$ Haematol. 2018;181(2):1-10. doi:10.1111/bjh.15087

9. Grassetto A, Fullin G, Lazzari F, et al. Perioperative ROTEM and ROTEMplatelet monitoring in a case of Glanzmann's thrombasthenia. Blood Coagul Fibrinolysis. 2017;28(1):96-9. doi:10.1097/ MBC. 0000000000000532

10. Budnik I, Shenkman B, Morozova O, Andreichyn ], Einav Y. Correction of coagulopathy in thrombocytopenia and Glanzmann thrombasthenia models by fibrinogen and factor XIII as assessed by thromboelastometry. Pathophysiology. 2018;25(4):347-51. doi:10.1016/j. pathophys.2018.05.005 